\title{
THE INFLUENCE OF EFFECTIVE LEADERSHIP AND ORGANIZATIONAL TRUST TO TEACHER'S WORK MOTIVATION AND ORGANIZATIONAL COMMITMENT
}

\author{
Diah Pranitasari \\ Sekolah Tinggi Ilmu Ekonomi Indonesia Jakarta \\ Email: nitadpranitasari@gmail.com; diah_pranitasari@stei.ac.id
}

Received: October 2019; Accepted: October 2019; Available online: January 2020

\begin{abstract}
This study aims to determine how the influence of organizational leadership and organizational effectiveness on work motivation and organizational commitment of teachers. This research was conducted at a private high school in Rawamangun Village, Pulo Gadung Sub District, East Jakarta. In this study using a saturated sample technique that is the entire population used as a sample, namely 115 respondents. The Partial Least Square Structural Equation Modeling (PLS-SEM) method was chosen as a statistical analysis technique. The results showed that the effectiveness of leadership and organizational trust had a direct positive effect on work motivation. The effectiveness of organizational leadership and trust has a direct positive effect on organizational commitment. Leadership effectiveness has a direct positive effect on organizational trust and work motivation has a direct positive effect on organizational commitment. The output of this research is that it can provide input for the school in determining policies specifically in determining the position requirements or the recruitment of school principals so that it is expected to increase the confidence, work motivation and commitment of teachers in school organizations.
\end{abstract}

Keywords: leadership effectiveness, organizational trust, work motivation, organizational commitment

\begin{abstract}
Abstrak
Penelitian ini bertujuan untuk mengetahui bagaimana pengaruh efektivitas kepemimpinan dan kepercayaan organisasional terhadap motivasi kerja dan komitmen organisasional guru. Penelitian ini dilakukan pada Sekolah Menengah Atas swasta di Kelurahan Rawamangun Kecamatan Pulo Gadung Jakarta Timur. Pada penelitian ini menggunakan teknik sampel jenuh yaitu seluruh populasi digunakan sebagai sampel, yaitu 115 responden. Metode Partial Least Square Structural Equation Modeling (PLS-SEM) dipilih sebagai teknik analisis statistic. Hasil penelitian menunjukkan bahwa efektivitas kepemimpinan dan kepercayaan organisasional berpengaruh langsung positif terhadap motivasi kerja. Efektivitas kepemimpinan dan kepercayaan organisasional berpengaruh langsung positif terhadap komitmen organisasional. Efektivitas kepemimpinan berpengaruh langsung positif terhadap kepercayaan organisasional dan motivasi kerja berpengaruh langsung positif terhadap komitmen organisasi. Luaran dari penelitian ini diharapkan dapat memberikan masukan bagi pihak sekolah dalam penetapan kebijakan khususnya dalam menetapkan persyaratan jabatan atau rekrutmen Kepala Sekolah sehingga diharapkan dapat meningkatkan kepercayaan, motivasi kerja dan komitmen para guru pada organisasi sekolah.

Kata Kunci: efektivitas kepemimpinan, kepercayaan organisasional, motivasi kerja, komitmen organisasional.

How to Cite: Pranitasari, D. (2020). The Influence of Effective Leadership and Organizational Trust to Teacher's Work Motivation and Organizational Commitment. Media Ekonomi dan Manajemen, 35(1), 75-91. doi:http://dx.doi.org/10.24856/ mem.v35i1.1257.
\end{abstract}




\section{INTRODUCTION}

Improving the quality of education is a major factor that determines the success of national development. The quality of education means that education graduates have the appropriate abilities, so they can make a high contribution to development. The quality of education, which is primarily determined by the teaching and learning process. In the teaching and learning process, the teacher plays an important role, the teacher is the creator of the teaching and learning process, meaning that a teacher must be able to develop a free atmosphere for students to study what is interesting and able to express their ideas and creativity within the limits of the norms that are consistently enforced. Teachers are a key element in the education system, especially in schools (Agustiana, 2014).

Teacher professionalism has an understanding of the nature that must exist in a teacher in carrying out his work so that the teacher can carry out his work with full responsibility and be able to develop his expertise which includes loyalty, responsibility and dedication (organizational commitment) high. With high organizational commitment, teachers will be able to provide good educational services. Teachers who have a high level of commitment, marked by the attention to students who are quite high, the time and energy expended to carry out their duties, and a lot of work for the interests of others (Aslil, 2012). The level of organizational commitment of teachers is influenced by many factors both from themselves (internal) and from the work environment (external). From within, for example, work motivation, awareness that work done as a religious service that will provide benefits to others and himself, while those from outside, such as career development provided career counseling, career mentoring and skills evaluation (Suparjo, 2019), the work atmosphere or organizational culture in educational insti- tutions, the leadership of school principals or administrators of foundations, completeness of facilities and infrastructure, material and non material welfare levels, sociocultural surrounding communities and so on (Armstrong and Taylor, 2014).

In responding to the basic needs of teachers in each organization is to build trust between themselves and the organization. A high level of trust in the organization encourages teacher performance. Trust in organizations refers to relationships established between teachers and organizations based on messages about organizational expectations and teacher perceptions of organizational management measurements (Hough, Green, and Plumlee, 2016).

The important role of teacher organizational commitment in improving the quality of education, it is deemed necessary to conduct research on teacher organizational commitment. Then this research will raise the title the influence of effective leadership and organizational trust to teacher's work motivation and organizational commitment.

\section{LITERATURE REVIEW}

\section{Organizational Commitment}

Ivancevich, Konopaske, and Matteson (2011) stated that commitment is a feeling of identification, involvement, and loyalty expressed by workers towards the company. Thus, commitment involves three characteristics: (a) a feeling of identification with the goals of the organization, (b) a feeling of being involved in organizational tasks, and (c) a feeling of loyalty to the organization.

Colquitt, LePine and Wesson (2015), organizational commitment is defined as the desire of some workers to remain members of the organization. According to Mowday cited by Armstrong and Taylor (2014) which states that commitment is characterized by an emotional attachment to one's organization that results from shared values of interest. Organizational commitment is 1) a strong desire to be- 
come a member in a group, 2) a high willingness for business for the organization, 3) a certain belief and acceptance of the values and goals of the organization. Furthermore Mowday cited by Armstrong and Taylor (2014) calls work commitment as another term of organizational commitment. According to him, organizational commitment is an important behavioral dimension that can be used to assess employee's tendency to stay as a member of an organization. Organizational commitment is the identification and involvement of someone who is relatively strong towards the organization.

Newstrom (2011) stated organizational commitment or employee loyalty is the level at which workers identify with the organization and want to continue actively participating in it. Organizational commitment is a measure of the desire of workers to remain in the company's future. Commitment is strongly related and bound to the organization on an emotional level. Often reflects the confidence of workers in the mission and goals of the company, the desire to develop a business in progress, and the intention to continue working there. Commitment is usually stronger among long-term workers, those who have personal success experience in the organization and those who work with committed work groups (Wibowo, 2016).

So organizational commitment in this study is the feelings, attitudes and behavior of individuals identify themselves as part of the organization, involved in the process of organizational activities and loyal to the organization in achieving organizational goals. Commitment is indicated by feelings of identification with organizational goals, feelings of being involved in organizational tasks, and feelings of loyalty to the organization.

\section{Leadership Effectiveness}

Yukl (2015) defines leadership is the process of influencing others to understand and agree about what needs to be done and how to do it, and the process of facilitating individual and collective efforts to accomplish shared objectives.

The same thing was also stated by Robbins and Judge (2015) who defines leadership as the ability to influence a group towards the achievement of a vision or goal set. Griffin (2015) says leaders are individuals who are able to influence the behavior of others without having to rely on violence; leaders are individuals who are accepted by others as leaders.

So leadership is someone who according to his position is able to influence, supervise, and direct his subordinates as individuals or groups in working to achieve organizational goals, with indicators of the ability to influence others, subordinates, and groups as well as the ability to direct the behavior of subordinates or others to achieve goals organization or group.

\section{Organizational Trust}

Organizational trust is very important in organizational success. Trust is an important issue for most organizations because it can have huge benefits for the organization. Organizational trust is defined as psychological state providing a feedback of how employees perceive the problems in the situations in which the organization is endangered (Vakola and Bouradas, 2011).

Ellonene et al. in Fard and Karimi (2015) explains that Interpersonal trust is divided into Lateral Trust and Vertical Trust. Lateral Trust is defined the trust of employees with each other and vertical trust is the trust between the employees and managers in organization. Mcknight et al., cyte by Fard dan Karimi (2015) institutional trust refers to one's belief regarding the position of institutional structures to fulfill the successful attitude and future of a person.

So organizational trust is an individual's belief in the integrity, fairness and reliability of an organization and accepts 
actions taken by the organization and cooperates with the organization, with dimensions of lateral, vertical and institutional trust.

\section{Work Motivation}

According to Armstrong and Taylor (2014) motivation is the strength and direction of behavior and the factors that influence people to behave in certain ways. Locke and Latham in Armstrong and Taylor (2014) state that the concept of motivation refers to internal factors that impel action and to external factors that can act as inducements to action. the concept of motivation refers to the internal factors that drive action and external factors that can act as an inducement to act.

Robbins and Judge (2015) describe motivation as a process that causes intensity (direction), direction (direction), and continuous effort (persistence) of individuals towards the achievement of goals. Intensity shows how hard someone is trying. But high intensity may not lead to good performance, unless efforts are made in the direction that benefits the organization. Therefore it must be considered the quality of the business and its intensity. Motivation has a dimension of continuous effort. Motivation is a measure of how long a person can maintain their business. Motivated individuals will carry out tasks long enough to achieve their goals.

Greenberg and Baron (2012) argue that motivation is a series of processes that arouse (direct), direct (direct), and maintain (maintain) human behavior toward achieving goals. Generating is related to the drive or energy behind an action. Motivation is also concerned with the choices people make and the direction of their behavior. While the behavior of maintaining or maintaining how long people will continue to strive to achieve goals.

It can be concluded that motivation is an impetus for a process of human behavior to achieve goals. While indicators in motivation include intensity (direction), direction (direction), and continuous effort (persistence).

\section{Hypothesis Development}

\section{Leadership and Organizational Com- mitment}

The success of an organization is determined by the ability of leaders to encourage and direct workers to achieve organizational goals. Organizational commitment as an attitude that shows employyee loyalty and is an ongoing process of how a member of the organization expressing their attention to success is strongly influenced by the ability of leaders.

Kochan and Dyer in Armstrong (2014) explain the factors that influence organizational commitment, namely: 1) Strategic Level: supportive business strategies, leaders who have commitment and policies in managing human resources; 2) Functional level: placement, investment in training and development and compensation; 3) Work Environment Level: selection process, task design and teamwork, work involvement in decision making and cooperative climate and trust.

In Zahra's study (2015) it was concluded that it was associated with positive and significant leadership on organizational commitment. Oztekin, Isci, and Karadag (2015) concluded in their research related to commitment to organizational commitment. The results of research conducted by Sabir, Sohail, and Khan (2011) also discussed leadership towards organizational commitment. Likewise Fasola, Adeyemi, and Olowe (2013) also concluded in their research that showed positive leadership towards organizational commitment.

$\mathrm{H} 1$ : There is a positive direct effect of leadership effectiveness on organizational commitment. 


\section{Leadership and Organizational Trust}

Bakiev (2013) states that the process of organizational trust creation in organizations is the responsibility of qualified managers and leaders. The role of managers and leaders in reforms in the organization is of great importance. The process of creating deep organizational trust is the responsibility of quality managers and leaders. The role of managers and leaders in reforms in organizations is very important.

Uslu and Oklay (2015) draw conclusions in research that leadership influences organizational trust. Rezaei et. al. (2012) states that leadership has a positive effect on organizational trust. Uslu and Oklay (2015) explain the correlation between leadership and employee confidence in the organization.

Employee trust in the organization is determined by the confidence of employees in their colleagues and leaders. In this case the leader has a big role to be able to increase employee confidence in the organization (Rahayuningsih, 2019). Rua and Araújo (2016) in the study found that there was a correlation between leadership and organizational trust.

$\mathrm{H} 2$ : There is a positive direct effect of leadership effectiveness on organizational trust.

\section{Leadership and Work Motivation}

Greenberg and Baron (2012) explain that motivation is the leader's duty to arouse, direct, and maintain the behavior of subordinates towards achieving goals. Generating is related to the drive or energy behind an action. Motivation is also concerned with the choices people make and the direction of their behavior. While the behavior of maintaining or maintaining how long people will continue to strive to achieve goals.

Alghazo and Al-Anazi (2016) produce the conclusion that leadership influences work motivation. Furthermore
Hersona and Sidharta (2017) also concluded that the leadership function has an impact on the work motivation of employyees and can improve employee performance in the Department of Manpower and Transmigration, Karawang Regency. Hanifah, Susanthi, and Setiawan (2014) explained the effect of leadership on employee work motivation which will ultimately affect employee performance.

The results of Rawung's research (2013) show that leaders directly influence motivation. Tezergil1, Köse1 \& Karabay (2014) also proved that leadership influences employee work motivation.

H3: There is a positive direct effect of leadership effectiveness on work motivation.

\section{Organizational Trust and Work Motiva- tion}

Altuntas and Baykal (2010) Organizational trust has a positive impact on increasing motivation, Organizational Citizenship Behavior, organizational commitment and job satisfaction. Employee trust in organizations continues to meet employee expectations in creating a reciprocal relationship between trust and fairness of the organization.

Jo and Lee (2012) show the influence of organizational trust on workers' motivation to create and innovate in completing their tasks. Guinot, Chiva, and Mallen (2013) conducted a study of the effect of organizational trust on employee performance by mediating employee work motivation, apparently organizational trust partially influenced employee work motivation.

Tezergil1, Köse1 \& Karabay (2014) empirically prove that organizational trust will influence employee work motivation. Verburg et al. (2018) expressed employee confidence in the organizations that employ them positively related to employee work motivation.

H4: There is a positive direct effect of organizational trust on work motivation. 


\section{Organizational Trust and Organizati- onal Commitment}

Workers who have a high level of organizational trust will encourage workers to have a commitment to the organization. Fard and Karimi (2015) concluded that organizational trust influences organizational commitment by 0.45 . Ghazinejad, Hussein and Zidane (2018) prove in their research that organizational trust and openness encourage mutual understanding, and encourages organizational commitment. Mohamed, Kader and Anisa (2012) produced the same research, namely organizational trust influences organizational commitment.

Martin and Siebert (2016) explain the influence of employee confidence in the organization where he works on organizational commitment. Chen (2015) also concluded in his research that organizational trust influences organizational commitment.

H5: There is a positive direct effect of commitment organizational on organizational commitment.

\section{Organizational Motivation and Commit- ment}

Gondokusumo and Sutanto (2015) show that motivation influences 0.386 on employee organizational commitment. Wardhani, Susilo, and Iqbal (2015) show that motivating factors significantly influence organizational commitment by 0.393 . The higher the motivation felt by the employee, the higher the level of commitment the employee has.

Furthermore Madi (2017) provides a conclusion in his research that employee motivation is correlated with organizational commitment. This is also supported by the results of research Curtis, Upchurch \& Severt (2009) which concluded that employee motivation affects organizational commitment.

H6: There is a positive direct effect of organizational motivation on organizational commitment.

\section{RESEARCH METHODS}

The location of the study was conducted at a Private High School in Rawamangun, Pulo Gadung, East Jakarta. The population in this study were all teachers in the Private High School of Rawamangun, Pulo Gadung, East Jakarta. The population in this study were all teachers in the Private High School in Rawamangun, Pulo Gadung, East Jakarta. Total population of 115 teachers, with the following distribution in Table 1.

The sampling technique used is saturated sample meaning that the entire population is used as a sample. Data analysis technique in this study uses Partial Least Square Structural Equation Modeling (PLS-SEM), a multivariate analysis technique which is a combination of regression analysis applied to the analysis of latent variables with factor analysis applied to the analysis of indicators (Sanjiwani et al., 2015; Chin, 1998).

The reason for using SEM analysis techniques is because this analysis technique is to be able to find out how the relationships occur between latent variables, but also to find out how the indicators of the formation of latent variables. Which forming indicators are dominant and how strong a latent variable can explain the variation that occurs in the forming indicators. This will deepen the discussion that can be given in this study.

In this study there are four variables, with leadership effectiveness and organizational trust as exogenous variables. While organizational commitment is an endogenous variable, and work motivation is an intervening variable. The research framework can be described as Figure 1.

\section{RESULT AND DISCUSSION}

The majority of private high school teachers in Kelurahan Rawamangun are aged 20-30, with the majority of undergraduate education levels being $90 \%$ and teachers with master level education at $10 \%$. The majority of tenure is less than 10 
years and $60 \%$ have been certified by teachers.

Outer model analysis is done by testing for convergent validity and composite reliability revealing loading factor values $>0.70$, average extracted variance $(\mathrm{AVE})>0.50$ and rho_A of $>$ 0.70 for each variable, indicating compatibility with the practical assessment rules measurement models recommended in relevant literature (Hair et al., 2017). The results of data processing in the calculation stage I was obtained there is still a loading factor value of less than 0.7 so that the manifest variable must be removed, namely KO9, KO11, EK25, EK26, EK27, EK28, EK29, K43, K44, K51, M53, M62, M66, M69, M70 and M71. Then the second stage is calculated again, there is still a manifest variable whose loading factor value is below 0.7, namely M64 and M65, then the two manifest variables must be removed and then the stage III calculation is done again. After calculating stage III, all manifest variables are above 0.7 , so that it is concluded that all manifest variables are valid (Table 2).

The results of the phase III calculation of convergent validity and composite reliability revealed loading factor values $>0.70$, mean extracted variance $(\mathrm{AVE})>0.50$ and rho_A of $>0.70$ meaning that all constructs of items in this model were reliable and valid. And the stage III chart is presented in Figure 2.

Table 3 shows the analysis of construct discriminant validity carried out using the Fornell and Larcker criteria. To do this, it has been verified that the square root of AVE of each construct that appears in the diagonal is greater than the correlation between the constructs displayed in the inferior part of this diagonal. In addition, these results are corroborated by correlation analysis between scores for each construct and for items belonging to other constructs or cross-loadings analysis. This result confirms that all indicators have a greater load on their own constructs than on other constructs that are included in the structural model (Hair et al., 2014).

In Table 2 it is known that the indicators forming the Leadership Effectiveness variable, namely the ability of the Principal to develop an effective and efficient school structure, have the greatest weight. Indicators forming the variable Organizational Trust, teachers believe the values in school are the dominant indicator. Indicators forming the dominant variable of Work Motivation are teachers becoming more motivated if the teachers plan the implementation of tasks so that they are in line with school goals, and the dominant indicator for the variable organizational commitment is the teacher's commitment to strive for the school to achieve its mission and goals.

Analysis of the inner model is done by looking at the path coefficient of direct influence, which is Figure 3.

H1: There is a positive direct effect of leadership effectiveness on organizational commitment.

The direct effect of leadership effectiveness on organizational commitment is 0.312 . This can be interpreted that the more effective a leader in this case is the principal, the teacher will increase commitment to the organization. This is in line with the research results of Zahra (2015), Oztekin, Isci, and Karadag (2015), Sabir, Sohail, and Khan (2011), Fasola. Adeyemi, and Olowe (2013) who also concluded that leadership influences organizational commitment.

H2: There is a positive direct effect of leadership effectiveness on organizational trust.

The direct effect of leadership effectiveness on organizational trust is 0.767 . This means that the more effective a leader or principal is in carrying out his or her duties, the greater the teacher's confidence in the organization. This supports the results of Uslu and Oklay (2015), 
Rezaei et. al. (2012), Uslu and Oklay (2015), Rahayuningsih (2019), Rua and Araújo (2016) which concluded that there is a direct influence of leadership on organizational trust.

\section{H3: There is a positive direct effect of leadership effectiveness on work motivation.}

The direct effect of leadership effecttiveness on work motivation is 0.531 . Which means that the more effective a school principal is in carrying out his duties, the more work motivation of the teacher will increase. The results of this study are in accordance with the results of Alghazo and Al-Anazi (2016), Hersona and Sidharta (2017), Hanifah, Susanthi, and Setiawan (2014), Rawung (2013), Tezergil1, Köse1 \& Karabay (2014) which also prove that leadership affects employee work motivation.

H4: There is a positive direct effect of organizational trust on work motivation.

The direct effect of organizational trust on work motivation is 0.283 . Which means the greater the teacher's trust in the organization will increase the work motivation of teachers. These results are in line with the results of research by Jo and Lee (2012), Guinot, Chiva, And Mallen (2013), Tezergil1, Köse1 \& Karabay (2014), Verburg et al. (2018) who also obtained results of employee trust research in the organizations that employ them positively related to employee work motivation.

H5: There is a positive direct effect of organizational trust on organizational commitment

The direct effect of organizational trust on organizational commitment amounted to 0.161 . This can be interpreted that the greater the teacher's level of trust in the organization will increase the teacher's commitment to the organization. This is consistent with the results of research by Fard and Karimi (2015), Ghazinejad, Hussein and Zidane (2018),
Mohamed, Kader and Anisa (2012), Martin and Siebert (2016), Chen et al. (2015) which also concluded in the study that organizational trust influences organizational commitment.

H6: There is a positive direct effect of work motivation on organizational commitment

The direct effect of work motivation on organizational commitment amounted to 0.191 . Which means the more motivated the teacher is in carrying out their duties and responsibilities, the higher the teacher's commitment to the organization. These results are consistent with the results of the research of Gondokusumo and Sutanto (2015), Wardhani, Susilo, and Iqbal (2015), Al Madi (2017), Curtis, Upchurch \& Severt (2009) who also suggested that employee work motivation influences organizational commitment.

The indirect effect of leadership effectiveness on work motivation through organizational trust is 0.12 . When compared with the direct effect of leadership effectiveness on work motivation which amounted to 0.531 , the indirect effect of leadership effectiveness on work motivation through organizational trust was declared insignificant. This can be interpreted that organizational trust is not effective as a mediating variable of leadership effectiveness on work motivation. While the effect of total leadership effectiveness and organizational trust on work motivation is 0.748 , this means that simultaneously the effectiveness of leadership and organizational trust has an effect of $78.33 \%$ on work motivation. This can be interpreted that the leadership role in this case is the role of the Principal in private high schools which includes the ability to influence and the ability to direct determine the work motivation of teachers.

The indirect effect of leadership effectiveness on organizational commitment through work motivation is 0.266 , the value is not greater than the direct effect of 
leadership effectiveness on organizational commitment, which means work motivation is not an effective variable mediating leadership effectiveness on organizational commitment. While the total effect of leadership effectiveness and work motivation variables on organizational commitment is 0.578 , this means that simultaneously the effectiveness of leadership and work motivation has a $58 \%$ effect on organizational commitment. From the results above, it can be interpreted that the teachers' trust in the school organization influences the work motivation of the teachers and the commitment of the teachers to the school organization where they work.

The indirect effect of organizational trust on organizational commitment through work motivation is 0.05 , this value is no greater than the direct effect of organizational trust on organizational commitment, meaning that work motivation is ineffective as a variable that mediates organizational trust on organizational commitment. While the effect of total organizational trust and work motivation on organizational commitment 0.215 , this means that simultaneously organizational trust and work motivation affect the organizational commitment of $21.5 \%$. Thus it can be interpreted that teachers' trust in school organizations both vertically, laterally and institutionally and with the increasing work motivation of teachers will also increase the commitment of teachers to school organizations.

Table 1. Number of Private High School Teachers in Rawamangun

\begin{tabular}{lc}
\hline \multicolumn{1}{c}{ Name of School } & Number of Teachers \\
\hline SMA Diponegoro & 39 \\
SMA LabSchool & 53 \\
SMA Muhammadiyah & 21 \\
SMA Tunas Markatin & 2 \\
\hline \multicolumn{1}{c}{ Total } & 115 \\
\hline $\begin{array}{c}\text { Source: Primary and Secondary Education Data, Jakarta Ministry of Education } \\
\text { and Culture (2019). }\end{array}$
\end{tabular}

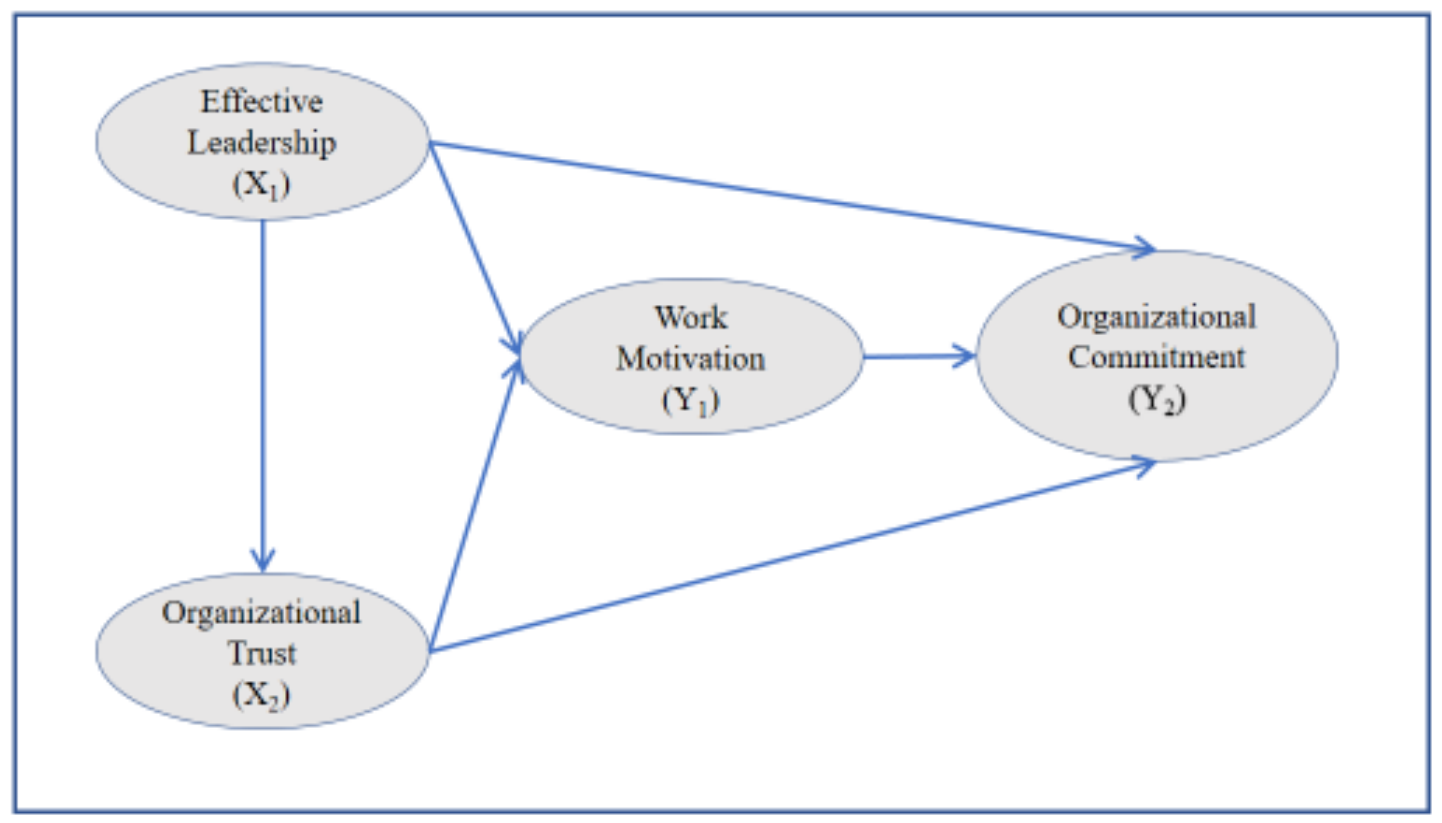

Figure 1. Research Framework 
Table 2. Measurement Results of Manifest and Model Variables

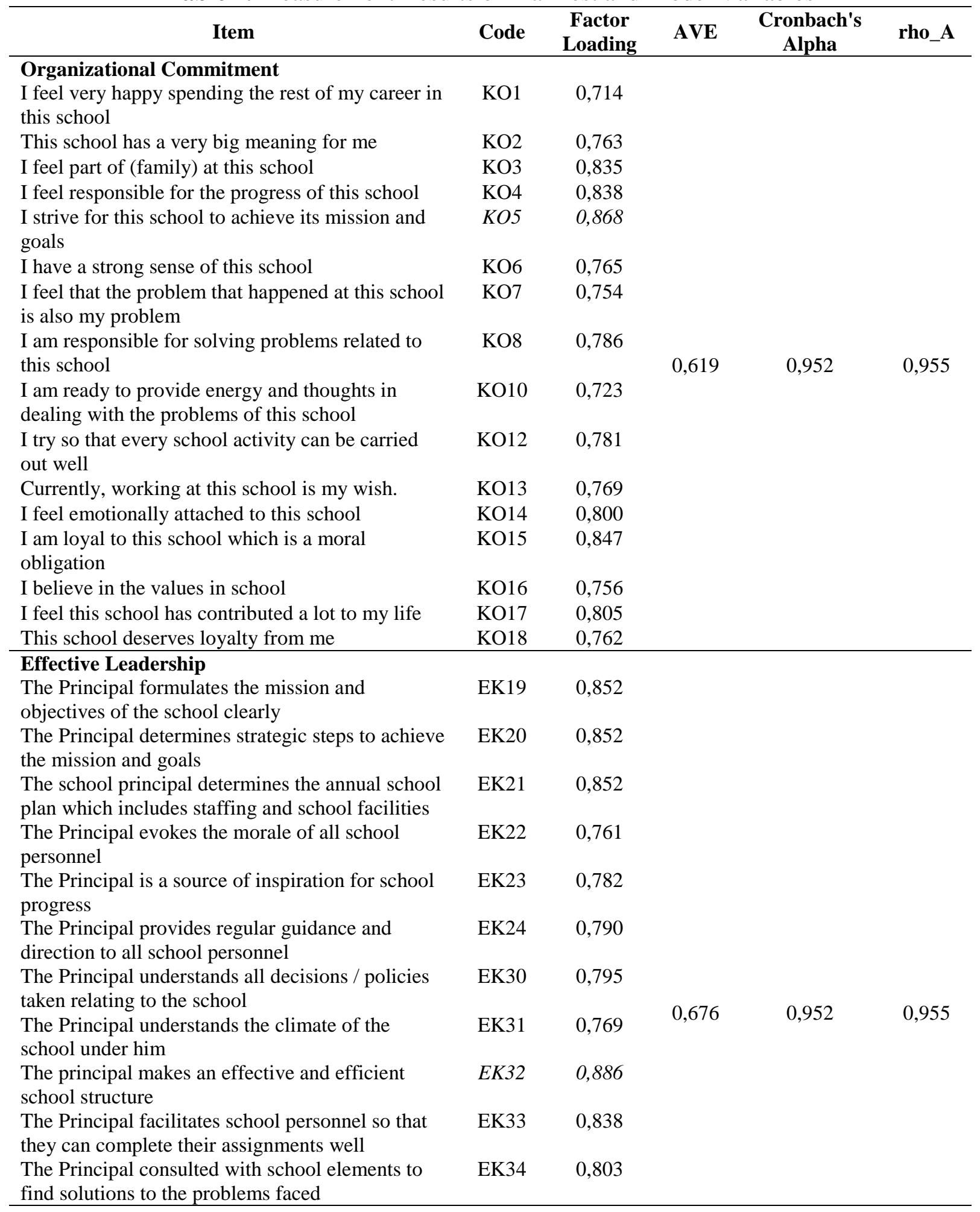


Table 2. Continue ...

\begin{tabular}{|c|c|c|c|c|c|}
\hline Item & Code & $\begin{array}{c}\text { Factor } \\
\text { Loading }\end{array}$ & AVE & $\begin{array}{c}\text { Cronbach's } \\
\text { Alpha }\end{array}$ & rho_A \\
\hline Organizational Trust & & & \multirow{16}{*}{0,649} & \multirow{16}{*}{0,961} & \multirow{16}{*}{0,964} \\
\hline $\begin{array}{l}\text { I believe the Principal has extensive } \\
\text { experience about the world of schools }\end{array}$ & K35 & 0,766 & & & \\
\hline $\begin{array}{l}\text { I believe the Principal has the ability to carry } \\
\text { out his duties properly }\end{array}$ & K36 & 0,826 & & & \\
\hline $\begin{array}{l}\text { I believe the Principal is able to bring this } \\
\text { school better }\end{array}$ & K37 & 0,812 & & & \\
\hline $\begin{array}{l}\text { I believe the Principal is fair to all school } \\
\text { personnel }\end{array}$ & K38 & 0,823 & & & \\
\hline $\begin{array}{l}\text { I believe the Principal is honest in carrying } \\
\text { out his leadership }\end{array}$ & K39 & 0,847 & & & \\
\hline $\begin{array}{l}\text { I believe the Principal instilled the right } \\
\text { values in this school }\end{array}$ & K40 & 0,773 & & & \\
\hline $\begin{array}{l}\text { I believe the policy set by the Principal for } \\
\text { the progress of the school }\end{array}$ & K41 & 0,835 & & & \\
\hline $\begin{array}{l}\text { I believe the Principal is able to achieve the } \\
\text { mission and goals }\end{array}$ & K42 & 0,785 & & & \\
\hline $\begin{array}{l}\text { I believe all teachers in this school feel as one } \\
\text { family }\end{array}$ & K45 & 0,757 & & & \\
\hline $\begin{array}{l}\text { I believe all teachers in this school try to } \\
\text { achieve the mission and goals of the school }\end{array}$ & K46 & 0,767 & & & \\
\hline $\begin{array}{l}\text { I believe all the teachers in this school want } \\
\text { this school to be even better }\end{array}$ & K47 & 0,851 & & & \\
\hline I believe in the values in this school & K48 & 0,889 & & & \\
\hline $\begin{array}{l}\text { I believe the regulations that apply in this } \\
\text { school are to improve the quality of schools }\end{array}$ & K49 & 0,820 & & & \\
\hline $\begin{array}{l}\text { I believe that the person in charge at this } \\
\text { school has a good personality }\end{array}$ & K50 & 0,772 & & & \\
\hline $\begin{array}{l}\text { I believe that the office holders in the school } \\
\text { structure are personnel who are able to } \\
\text { improve the quality of the school }\end{array}$ & K52 & 0,747 & & & \\
\hline \multicolumn{3}{|l|}{ Work Motivation } & \multirow{12}{*}{0,654} & \multirow{12}{*}{0,946} & \multirow{12}{*}{0,950} \\
\hline I try to carry out the tasks given my best & M54 & 0,843 & & & \\
\hline $\begin{array}{l}\text { I try to develop teaching methods that are } \\
\text { suitable for the class that I am facing }\end{array}$ & M55 & 0,845 & & & \\
\hline $\begin{array}{l}\text { I try to overcome the problems that arise as } \\
\text { well as possible }\end{array}$ & M56 & 0,724 & & & \\
\hline $\begin{array}{l}\text { I help teachers who have difficulty in } \\
\text { carrying out work }\end{array}$ & M57 & 0,797 & & & \\
\hline $\begin{array}{l}\text { I understand the mission and goals of the } \\
\text { school }\end{array}$ & M58 & 0,885 & & & \\
\hline $\begin{array}{l}\text { I try to carry out the task well so that the } \\
\text { school's goals can be achieved }\end{array}$ & M59 & 0,840 & & & \\
\hline $\begin{array}{l}\text { I plan the implementation of my tasks so that } \\
\text { they are in line with the school's goals }\end{array}$ & M60 & 0,925 & & & \\
\hline $\begin{array}{l}\text { The school principal gives encouragement to } \\
\text { all school personnel in order to achieve } \\
\text { school goals }\end{array}$ & M61 & 0,760 & & & \\
\hline I can finish teaching according to the syllabus & M63 & 0,750 & & & \\
\hline $\begin{array}{l}\text { I try to follow all the rules that apply as well } \\
\text { as possible }\end{array}$ & M67 & 0,784 & & & \\
\hline $\begin{array}{l}\text { I obey the instructions given by the school } \\
\text { principal }\end{array}$ & M68 & 0,712 & & & \\
\hline
\end{tabular}

Source: Data Processed, 2019 


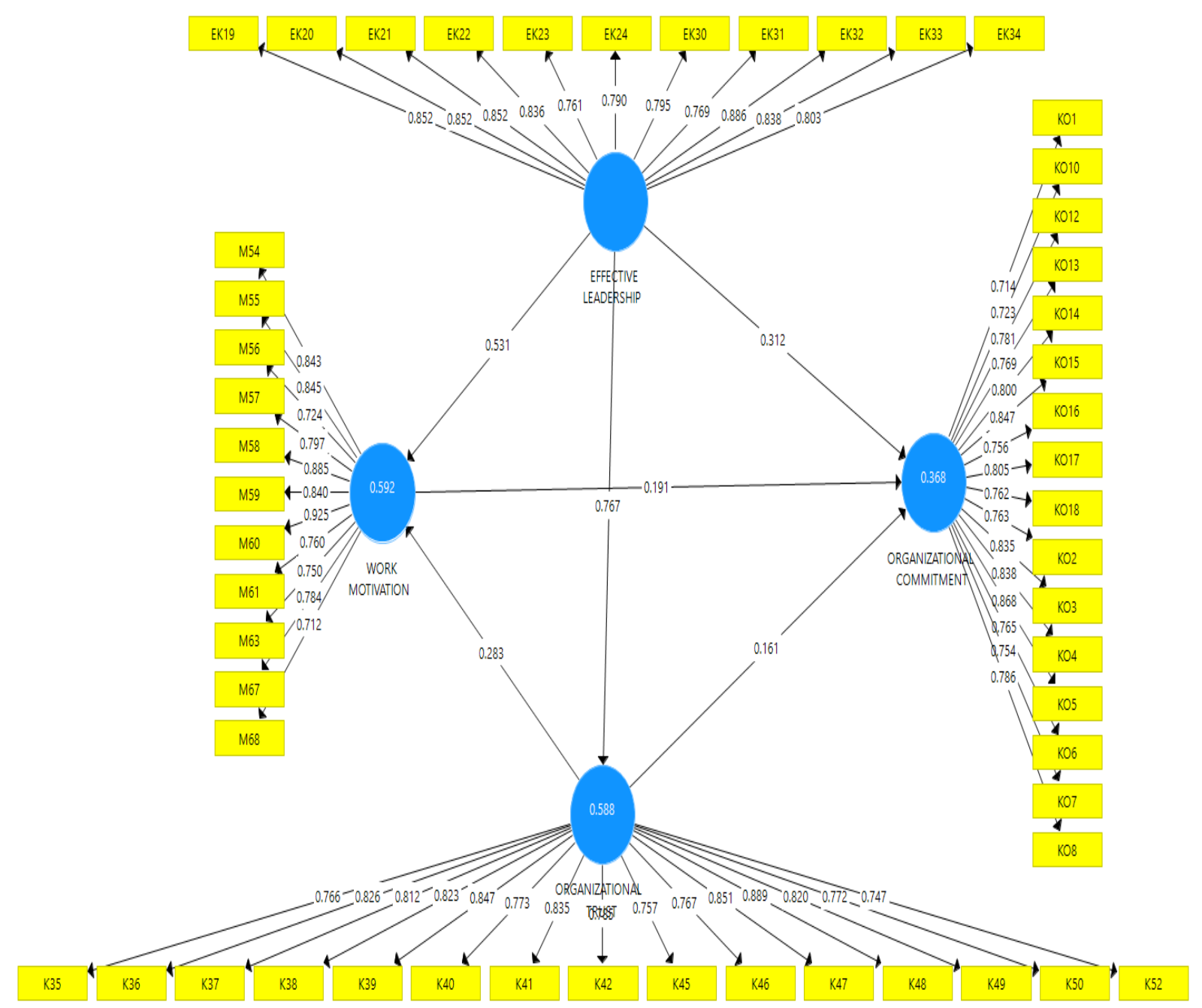

Figure 2. Calculation Results with Fit Models

Tabel 3. Discriminant Validity

\begin{tabular}{lcccc}
\hline & $\begin{array}{c}\text { Effective } \\
\text { Leadership }\end{array}$ & $\begin{array}{c}\text { Organizational } \\
\text { Commitment }\end{array}$ & $\begin{array}{c}\text { Organizational } \\
\text { Trust }\end{array}$ & $\begin{array}{c}\text { Work } \\
\text { Motivation }\end{array}$ \\
\hline Effective Leadership & $\mathbf{0 , 8 2 2}$ & & & \\
Organizational Commitment & 0,578 & $\mathbf{0 , 7 8 7}$ & & \\
Organizational Trust & 0,767 & 0,532 & $\mathbf{0 , 8 0 6}$ & \\
Work Motivation & 0,748 & 0,535 & 0,690 & 0,808 \\
\hline
\end{tabular}

Sources: Data proceed, 2019 


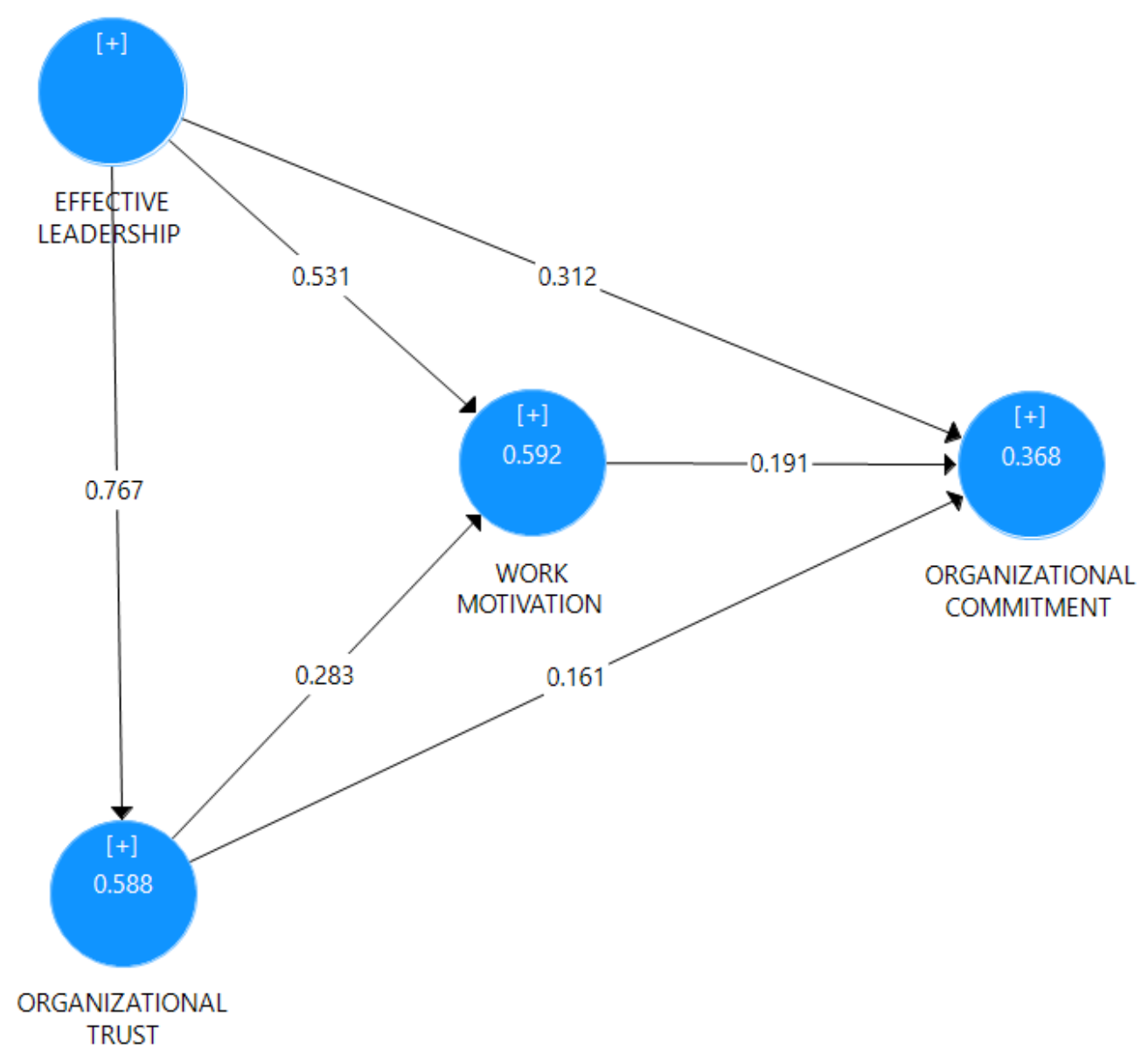

Figure 3. Direct Effects between Latent Variables

Tabel 4. Indirect and Total Effect

\begin{tabular}{llcc}
\hline \multicolumn{1}{c}{ Path } & \multicolumn{2}{c}{ Influence } \\
\cline { 2 - 4 } & \multicolumn{1}{c}{ Indirect } & Total \\
\hline $\begin{array}{l}\text { Effective Leadership } \rightarrow \text { Organizational Trust } \rightarrow \\
\text { Work Motivation }\end{array}$ & 0,12 & 0,748 \\
$\begin{array}{l}\text { Effective leadership } \rightarrow \text { Work Motivation } \rightarrow \\
\text { Organizational Commitment } \\
\text { Organizational Trust } \rightarrow \text { Work Motivation } \rightarrow\end{array}$ & 0,266 & 0,578 \\
Organizational Commitment & & 0,05 & 0,215 \\
\hline
\end{tabular}

\section{CONCLUSION AND RECOMMENDA-} TION

\section{Conclusion}

Leadership effectiveness has an influence contribution of 0.531 on work motivation. Organizational trust has an influence contribution of 0.283 on work motivation. Effectiveness of leadership and organizational trust together affect the variable work motivation by 0.592 .
Leadership effectiveness contributes more when compared to the contribution of organizational trust.

Leadership effectiveness has an influence contribution of 0.312 to the variable organizational commitment. Organizational trust has an influence contribution of 0.161 to organizational commitment. Work motivation contributes 0.191 to organizational commitment. The effec- 
tiveness of leadership, organizational trust and work motivation together affect the organizational commitment of 0.368 .

\section{Recommendation}

Suggestions are given because leadership effectiveness has a major influence on work motivation and organizational commitment, so the headmaster should be able to optimize his role in influencing and directing teachers, especially in the preparation of effective and efficient school organizational structures. In addition, the organizational trust of teachers is also strongly influenced by the role of the principal, so the principal should be able to further increase the teachers' trust in the school organization, especially in establishing the values agreed upon and believed by the school in developing the world of education.

\section{REFERENCES}

Agustiana, N. (2014). Pentingnya Peran Guru Dalam Peningkatan Mutu Pendidikan. Kompas. http://www. kompasiana.com/nia1714/pentingnya -peran-guru-dalam-peningkatanmutu-pendidikan_552915326ea8345 b3f8b4587.

Al-Madi, F. N., Assal, H., Shrafat, F., \& Zeglat, D. (2017). The impact of employee motivation on organizational commitment. European Journal of Business and Management, 9(15), 134-145.

Alghazo, A \& Al-Anazi, M. (2016). The Impact of Leadership Style on Employee's Motivation International. Journal of Economics and Business Administration, 2(5), 37-44.
Altuntaș, S \& Baykal, U. (2010). Relationship between nurses' organizational trust levels and their organizational citizenship behaviors. Journal of Nursing Scholarship, 42(2), 186-194.

Amstrong, M \& Taylor, S. (2014). Amstrong's Handbook Of Human Resources Practice: Hongkong: Graphicraft Limited.

Aslikan, A. (2012). Pengertian Prestasi Belajar. Pustaka Aslikan. http:// pustakaaslikan.blogspot.com/2012/0 6/pengertian-prestasibelajar. html. (diakses 20 Mei 2019).

Bakiev, E. (2013). The influence of interpersonal trust and organizational commitment on perceived organizational performance. Journal of Applied Economics and Business Research, 3(3), 166-180.

Chen, S. Y., Wu, W., Chang, C., Lin, C., Kung, J., Weng, H., Lin, Y., \& Lee, S. (2015). Organizational justice, trust, and identification and their effects on organizational commitment in hospital nursing staff. BMC Health Services Research, 15(1), 363-379.

Chin, W. W. (1998). The Partial Least Squares Approach to Structural Equation Modeling. Modern Methods for Business Research, 295(2), 295-336.

Colquitt, J..A., LePine, J.A., \& Wesson, M. J. (2015). Organizational Behaviour. New York: McGraw-Hill International Companies.

Curtis, C.R., Upchurch, R.S. \& Severt, D.E.. (2009). Employee Motivation and Organizational Commitment: A Comparison of Tipped and Nontipped Restaurant Employees. International Journal of Hospitality \& Tourism Administration, 10(3):253269. DOI: $10.1080 / 1525648090$ 3088469 . 
Fard, P. G., \& Karimi, F. (2015). The Relationship between Organizational Trust and Organizational Silence with Job Satisfaction and Organizational Commitment of the Employees of University. International Education Studies, 8(11), 197-217.

Fasola, O., Adeyemi, M., \& F. Olowe. (2013). Exploring the relationship between transformational, transactional leadership style and organizational commitment among Nigerian banks employees. International Journal of Academic Research in Economics and Management Sciences, 2(6):96.

Ghazinejad, M., Hussein, B, A., \& Zidane, Y. J.T. (2018). Impact of Trust, Commitment, and Openness on Research Project Performance: Case Study in a Research Institute. Socal Science Journal, 7(2), 22; doi:10. 3390/socsci7020022.

Gondokusumo, S. \& Sutanto, E. M. (2015). Motivasi Kerja, Kepuasan Kerja, dan Komitmen Organisasional Karyawan. JMK, 17(2), 186-196.

Greenberg \& Baron. (2012). Behavior in organizations. Boston, MA: Allyn\& Bacon.

Griffin, R.W. (2015). Manajemen. Jakarta: Erlangga.

Guinot, J., Chiva, R., \& Mallen, F. (2013). Organizational Trust And Performance: Is Organizational Learning Capability A Missing Link?. Journal Of Management \& Organization, 19(5)

559-582.

Doi:10.1017/Jmo.2014.3

Hair, J.F., Hult, G.T.M., Ringle, C.M. and Sarstedt, M. (2014). A Primer on Partial Least Squares Structural Equation Modeling (PLS-SEM), Sage Publications, Thousand Oaks, CA
Hair, J.F., Hult, G.T.M., Ringle, C.M., Sarstedt, M., (2017). A Primer on Partial Least Squares Structural Equation Modeling (PLS-sem), second ed. Sage Publications, Thousand Oaks.

Hanifah, H., Susanthi, N. I., \& Setiawan, A. (2014). The Effect of Leadership Style on Motivation to Improve the Employee Performance. Jurnal Manajemen Transportasi \& Logistik, 1(3), 221-226.

Hersona, S. \& Sidharta, I. (2017). Influence Of Leadership Function, Motivation And Work Discipline On Employees' Performance. Jurnal Aplikasi Manajemen, 15(3), 528-537. Doi: Http://Dx.Doi.Org/10.21776/Ub .Jam.2017.015.03.18

Hough, C., Green, K., \& Plumlee, G. (2015). Impact of ethics environment and organizational trust on employee engagement. Journal of Legal, Ethical and Regulatory Issues, 18(3), 45.

Ivancevich, J.M., Konopaske, R., \& Matteson, M.T. (2011). Organizational Behavior and Management. $9^{\text {th }}$ Edition. New York: McGraw-Hill International.

Jo, N. Y., \& Lee, K. C. (2012). The Effect Of Organizational Trust, Task Complexity, Instrinsic Motivation on Employee Creativity: Emphassing on Moderating Effect of Stress. Spinger Science And Business Media DorDrecht.

Martin, G \& Siebert, S. (2016). Managing People and Organizations in Changing Contexts. Reutlege: New York. 
Mohamed, M. S., Kader, M. M.A., \& Anisa, H.. (2012). Relationship among Organizational Commitment, Trust and Job Satisfaction: An Empirical Study in Banking Industry. Research Journal of Management Sciences. 1(2), 1-7.

Newstrom, J. W. (2011). Organizational Behavior: Human Behavior at Work. Newyork-America: McGraw-Hill Education.

Oztekin, O, Isci, S., \& Karadag, E. (2015). The Effect of Leadership on Organizational Commitment. Springer International Publishing, Switzerland. DOI 10.1007/978-3-31914908-0_4.

Rahayuningsih, I. (2019). The Positive Impact Of Organizational Trust: A Systematic Review. Journal of Educational, Health, Community Psychology, 2088-3129. DOI: http:// dx.doi.org/10.12928/jehcp.v8i1.1219 5.

Rawung, F.H. (2013). The Effect of Leadership on the Work Motivation of Higher Education Administration Employees. IOSR Journal of Business and Management (IOSRJBM), 15(1), 28-33.

Rezaei, M., Salehi, S., Shafiei, M., \& Sabet, S. (2012). Servant leadership and organizational trust: The mediating effect of the leader trust and organizational communication. EMAJ: Emerging Markets Journal, 2(1), 70-78. Doi 10.5195/Emaj. 2012.21 .

Robbins, S.P \& Judge, T. A.. (2015). Perilaku Organisasi, Edisi 16. Jakarta: Salemba Empat.

Rua, O. M. M. M. D. L., \& Araújo, J. M. C. (2016). Linking transformational leadership and organizational trust: has organizational commitment a mediating effect on it?. Cuadernos de Gestión, 16(1) 43-62.
Sabir, M.S., Sohail, A, \& Khan, M, A. (2011). Impact of leadership style on Organization Commitment. Journal of Economics and Behavioral Studies, 3(2), 145-152.

Sanjiwani, M., Jayanegara, K., Eka, I. P., \& Kencana, N. (2015). Analisis Kepuasan Konsumen Restoran Cepat Saji Menggunakan Metode Partial Least Square (Studi Kasus: Burger King Bali). Jurnal Matematika 4(3), 98-103. DOI: https://doi.org/10. 24843/MTK.2015.v04.i03.p095

Suparjo. (2019). The Role of Career Development in Improving Employee Performance: Empirical Study on Private Higher Education in Central Java, Indonesia. Media Ekonomi dan Manajemen, 34(2), 193-205.

DOI: $10.24856 /$ mem.v34i2.1031.

Tezergil1, S. A., Köse1, A., \& Karabay, M. E. (2014). Investigating the Effect of Trust, Work-Involvement, Motivation and Demographic Variables on Organizational Commitment: Evidence from IT Industry. International Journal of Business and Management; 9(12), 111-122. doi:10.5539/ijbm.v9n12p111.

Uslu, F. \& Oklay, E. (2015). Leadership and Organizational Outcomes MetaAnalysis of Empirical Studies: The Effect of Leadership on Organizational Trust. Spinger International Publishing Switzerland. ISBN 978-3319-14907-3 ISBN 978-3-31914908-0 (eBook). DOI 10.1007/9783-319-14908-0

Vakola, M. \& Bouradas, D. (2011). Antecedents and Consequences of Organisational Silence: an Empirical Investigation. Emerald Group Publishing Limited, 27(5), 441-458. 
Verburg, R. M., Nienaber, R. H. S., Weibel, A., Hartog, D. N. D., \& Rupp, D. E. (2018). The Role of Organizational Control Systems in Employees' Organizational Trust and Performance Outcomes. Group and Organization Management, 43(2), 179-206. Doi: 10.1177/105960111 7725191.

Wardhani, W. K., Susilo, H., \& Iqbal, M. (2015). Pengaruh Motivasi Kerja Terhadap Komiten Organisasional Dengan Kepuasan Kerja Sebagai Variabel Intervening pada PT.ABC Industrial Malang. Jurnal Administrasi Bisnis (JAB), 2(1), 1-10.

Wibowo. (2016). Manajemen Kinerja. Jakarta: Rajawali.

Yukl, G. (2015). Kepemimpinan Dalam Organisasi Edisi kelima. Jakarta: PT. Indeks.

Zahra, N. (2015). Pengaruh Gaya Kepemimpinan Terhadap Komitmen Organisasi Melalui Aspek Kepuasan Kerja Karyawan dan Kepercayaan Pada Sektor Perbankan. Jurnal Manajemen dan Pemasaran Jasa, 8(1), 145-162. 